Estonian Journal of Archaeology, 2020, 24, 2, 141-160

https://doi.org/10.3176/arch.2020.2.02

\author{
Jari-Matti Kuusela, Anna-Kaisa Salmi and Tiina Äikäs
}

\title{
HUNTERS, FISHERS, TRADERS - AN \\ ARCHAEOLOGICAL AND ZOOARCHAEOLOGICAL PERSPECTIVE ON THE DEVELOPMENT OF THE LATE IRON AGE AND MEDIEVAL NORTHERN FENNOSCANDIAN TRADE NETWORK
}

Late Iron Age and medieval trade in northern Fennoscandia has arguably often thought to have been primarily fur trade. However, recent discoveries of Late Iron Age and early medieval sites in the north together with the re-examination of previous evidence reveals a more nuanced picture and indicates that trade in bulk goods - namely inland stockfish and reindeer products may have played a significant role in the northern trade. This article examines both archaeological and zooarchaeological evidence from several sites in northern Fennoscandia from the perspective of trade economy, and it is suggested that the northern trade began to flourish at the beginning of the Viking Age in the early 9th century and may have been driven by the demand of fish by the European markets. It is also suggested that at the beginning of the 13th century at the latest, the trade economic importance of reindeer became prominent and would increasingly remain so up until the historical period. The authors therefore suggest that although the role of furs in the northern trade was significant, reindeer hunting and inland fishing should also be considered to have been of major trade economic importance.

Jari-Matti Kuusela, The Regional Museum of Lapland, Pohjoisranta 4, FI-96200 Rovaniemi, Finland; jari-matti.kuusela@rovaniemi.fi,jmt.kuusela@gmail.com Anna-Kaisa Salmi, Department of Archaeology, P.O. Box 8000, FI-90014 University of Oulu, Finland; anna-kaisa.salmi@oulu.fi

Tiina Äikäs, Department of Archaeology, P.O. Box 8000, FI-90014 University of Oulu, Finland; tiina.aikas@oulu.fi 


\section{Introduction}

During 800-1600 AD, northern Fennoscandia (Fig. 1) was an arena of intense economic and social developments, and during the course of these centuries it became an arena for the power struggles of the emerging states of the Baltic region. The Christianisation process also began, as well as the domestication of reindeer and the development of reindeer breeding with its consequential cultural transformations. At the heart of these developments was the economic interest directed by Europe towards northern Fennoscandia from the Viking Age onwards and the resulting trade.

The interaction of the northern communities with Europe via an extensive trade network during the Late Iron Age and Middle Ages has in recent years become a well researched subject, and cultural interactions (Bergman \& Edlund 2016; Kuusela et al. 2016; Kuusela 2018), the power struggles of the Baltic powers and their effect on the northern societies (Kuusela et al. 2018), the extent of the network (Kuusela et al. 2016; Hakamäki 2018; Henriksen 2019), and the Christianisation process (Kuusela 2015; in press; Puolakka 2019) have been examined, showing that the trade network acted as a superstructure influencing the trajectories of cultural development in northern Fennoscandia. However, the processes via which the network came to be in existence have been under less scrutiny. In this paper we focus on the birth of the trade network by examining the role inland fishing and the hunting economy played in its formation. When examining the role of fishing, we will be specifically focusing on the role of inland fisheries, but the coeval development of marine fisheries falls outside the scope of the paper. In the future, however, studying both these subjects side by side might lead to interesting insights regarding the economic networks of Late Iron Age and medieval northern Fennoscandia.

We will combine archaeological and zooarchaeological evidence and show present how certain features in the assemblages point towards a relationship between fishing and hunting - specifically pike fishing and reindeer hunting - and increasing economic activity in northern Fennoscandia beginning in the 9th century AD. Specifically, we will put forward the argument that it was the increase in the importance of inland fishing and hunting of land mammals that facilitated the integration of northern Fennoscandia into the European trade network on scale not seen prior to the Viking Age. Additionally, we will examine the potential impact this trade had on the process of the domestication of reindeer.

\section{A note on chronological terminology}

It is challenging to come up with a unified chronological terminology for the area studied in this paper, as it is divided between several states that have differing terminology for the periods of Iron Age and the beginning of the Middle Ages. The examined region primarily comprises the interior part of northern Fennoscandia, and the archaeological evidence examined in this paper falls mostly within the 


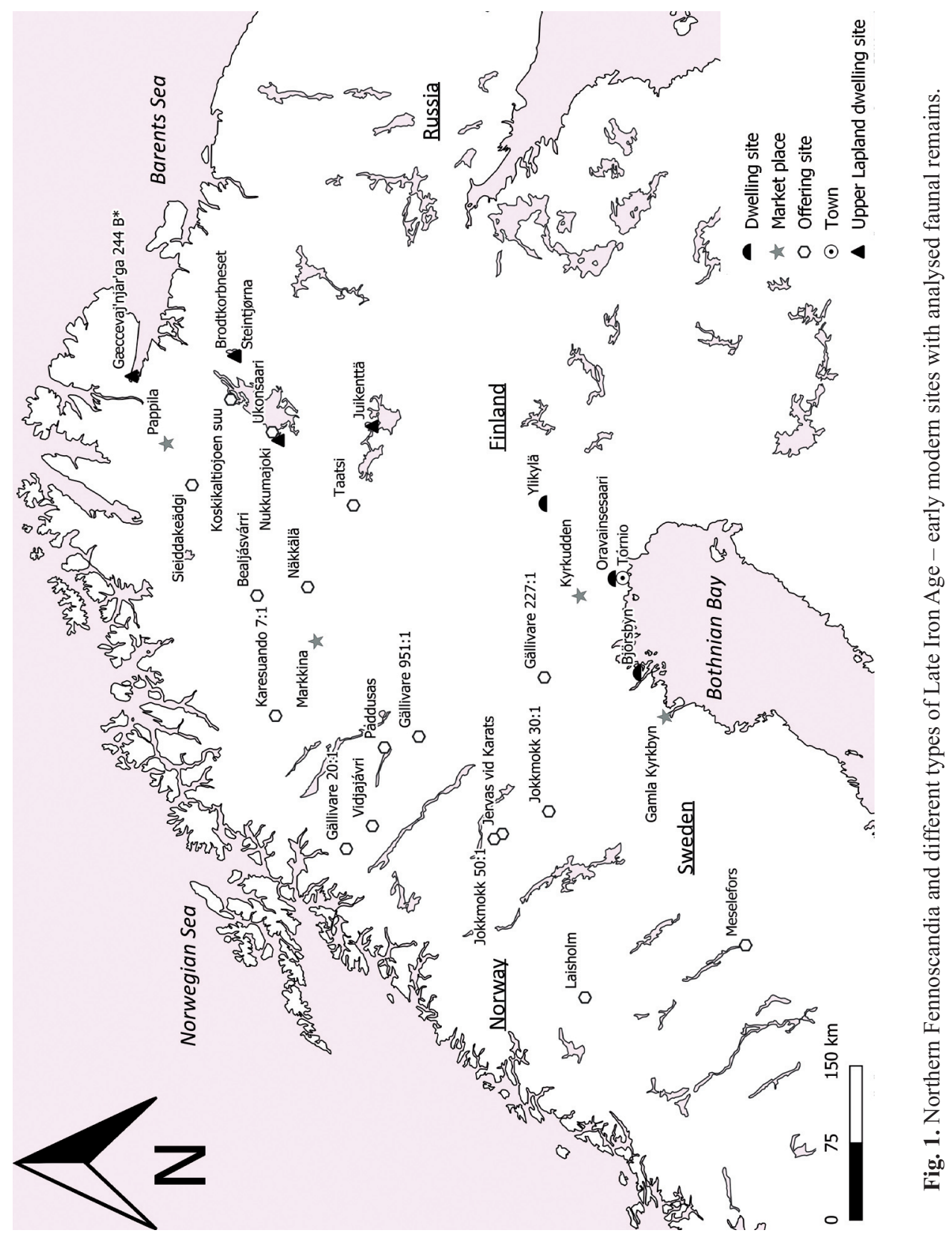


Table 1. Chronological terminology used in this paper. Chronology and terminology follows the conventional Finnish periodisation of the south-eastern part of the country

\begin{tabular}{|l|c|c|}
\hline Pre-Roman Iron Age & $500-1 \mathrm{BC}$ & \multirow{2}{*}{ Early Iron Age } \\
\hline Early Roman Iron Age & $1-200 \mathrm{AD}$ & \\
\hline Late Roman Iron Age & $200-400 \mathrm{AD}$ & \multirow{2}{*}{ Middle Iron Age } \\
\hline Migration Period & $400-600$ AD & \multirow{2}{*}{ Late Iron Age } \\
\hline Merovingian Period & $600-800$ AD & \\
\hline Viking Age & $800-1050$ AD & \multirow{2}{*}{ Historical period } \\
\hline Crusade Period & $1050-1300$ AD & \\
\hline Middle Ages & $1300-1600$ AD & \\
\hline Early Modern Period & Post-16th century & \\
\hline
\end{tabular}

borders of the present-day states of Finland and Sweden, with the former being more pronounced, and thus we have made the choice of using the conventional (eastern) Finnish chronology regarding the phases of the Iron Age (Table 1).

\section{Northern Fennoscandia before and after the Viking Age}

Archaeological evidence indicates that the Viking Age is a watershed period in northern Fennoscandia. Finds and sites dating to periods before the Viking Age are relatively few in the north with a considerable number of sites concentrating specifically on the coastal regions of the Bothnian Bay. This coast-favouring trend is visible at least since the Bronze Age, and though the inland is by no means empty during the time, it is less pronounced (Kuusela 2013; 2014). At the beginning of the Viking Age the archaeological profile of the inland regions of northern Fennoscandia becomes more pronounced while the number of archaeological finds and sites begins to generally increase, reaching a peak between roughly the early 11 th and the end of the 13th century before beginning to decline during the Middle Ages (e.g. Kuusela 2013, 76 ff.; 2014; Fig. 2).The data in Fig. 2 consists of sites and datable finds in both northern Finland and Sweden, but the chronological categorisation of especially individual stray finds is sometimes challenging due to an often wide dating range of some artefact types, such as the so-called oval firestriking stones which are conventionally dated to have been in use between ca 200-800 AD. However, even as we have excluded finds with a wide dating range and only included excavated and dated sites and such individual finds that can be dated with more precision into Fig. 2, the difference between the early-to mid-Iron 


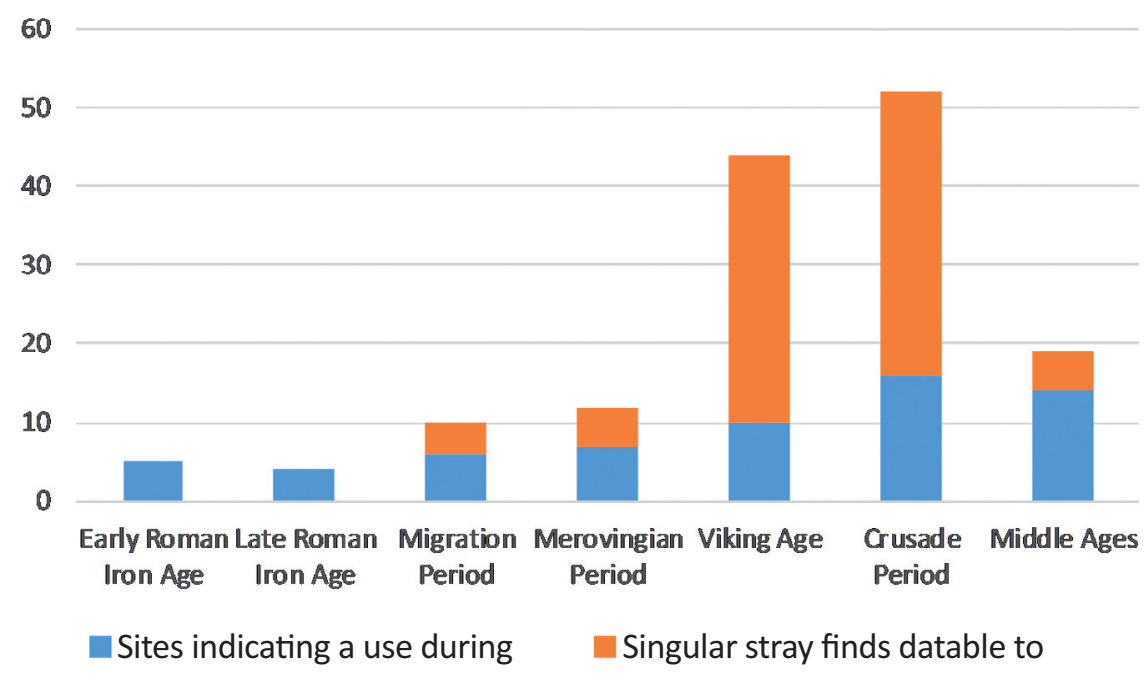

Fig. 2. Dated Iron Age and medieval archaeological finds \& sites by period in northern Finland and Sweden.

Ages and the Late Iron Age-Middle Ages is nevertheless relatively clear, indicating that human activity, resulting in a visible archaeological record, did probably increase in the north from the Viking Age onwards.

Key features in the archaeological records of the north are the tendency of sites and finds to be associated with waterways, associated water systems, and travelling routes (Hakamäki \& Kuusela 2013; Kuusela et al. 2018, 774), and that a significant part of the archaeological material of the period consists of imported artefacts, implicating a wide trade network (see e.g. Wallerström 1995; Hakamäki \& Kuusela 2013; Hakamäki 2018; Kuusela et al. 2016; 2018; Kuusela 2018; Henriksen 2019). From the Late Iron Age onwards, European traders began showing an increased interest towards northern trade - as the products of the north where in high demand (e.g. Wallerström 1983, 33 ff.; Martin 1986; 1995, 134 ff., 166 ff.; Vahtola 1990; 1997, 64 ff.; Sawyer \& Sawyer 1993, 158 f.) - the sharp increase in the number of archaeological finds and sites in the north should be linked with an increasing economic pressure directed towards the north. However, the structure of this northern economy is of some interest, as, conventionally, the affluence of the north has been interpreted to having been in fur-bearing animals and thus in high-quality furs. The archaeological record, however, paints a slightly more varied picture.

\section{The northern economy via zoological evidence}

The wealth of the north was in wildlife - furs are a well-known and often cited northern export, but other products, such as fish, found markets in Europe, especially during the Middle Ages (see e.g. Barrett 2016; 2019; Barrett et al. 2011; 
Star et al. 2017). Interestingly, reindeer may have been an important trade commodity early on with pelts, antlers and meat all being traded (e.g. Pilø et al. 2018; Salmi \& Heino 2019). The first systematic records of reindeer pelts exported into England, for example, date from the early 14th century, but this trade practice may have begun earlier than the first preserved historical records (Pilø et al. 2018, 1). Trade of reindeer antler from the north into Denmark in turn is known to have occurred at least already in the early 8th century (Pilø et al. 2018, 1).

In contrast, fur-bearing animals are not nearly as visible in the archaeological records as are the reindeer. When examining the faunal evidence of several types of sites - such as offering sites, dwelling sites, and marketplaces and towns reindeer and fish tend to take clear precedence over fur-bearing animals (Table 2, Fig. 3).

The faunal assemblages from dwelling sites in upper Lapland (ca 1000-1650) and offering sites (ca 500-1650) are dominated by reindeer (ca $80 \%$ of NISP identified to species or genus), indicating that reindeer were predominant in the economic and religious lives of the local communities. It must be pointed out, however, that certain problems compound the interpretation of dwelling site materials. Many of the sites date to a very long period of time, for example, Nukkumajoki dates to ca 1050-1650. Moreover, the sites are located in different geographic areas, naturally reflected in the use of environmental resources. A good example of this is the utilisation of fish, which was important among the communities in coastal areas of the Arctic Sea and on the shores of inland lakes. Season of occupation is also reflected in the faunal material - Nukkumajoki was a winter dwelling site, and fishing was probably not as important in the winter as it was during the spring and summer.

Approximately $25 \%$ of the faunal remains from excavated trading places (marketplaces and towns) are reindeer bones. A distinctive difference exists in the faunal assemblages of the two northernmost market-places (Markkina and Pappila), which are dominated by reindeer bones, and trading places in the Tornio River Valley (market-places in Kyrkudden and Gamla Kyrkbyn, and the town of Tornio), dominated by livestock bones with a share of ca $1-15$ of reindeer bones. The skeletal frequencies of trading place assemblages indicate that all reindeer body parts, including meat-poor parts that were not likely to be traded, such as cranium and lower extremities, are represented in the assemblages (Puputti 2010; Harlin et al. 2019; Salmi \& Heino 2019), suggesting that the animals were slaughtered and at least partly consumed locally, perhaps as a part of market-related festivities and feasting (see Kuusela 2018). However, in the town of Tornio, elements associated with high meat content, such as the humerus, were clearly overrepresented (Puputti 2010, 32 ff.) indicating meat trade. It should be remembered that many of the reindeer products traded at these sites (hides and reindeer leather goods) have left no faunal remains on the site and the bones therefore probably represent meat both traded and eaten.

All faunal assemblages from southern dwelling sites (Oravaisensaari, Ylikylä, Björsbyn) contain reindeer bones, ca $10 \%$ of NISP identified to species or genus. It 
Table 2. Faunal evidence. Offering site faunal evidence has been published and disseminated in Salmi et al. 2018

Southern dwelling sites

\begin{tabular}{|l|c|c|c|c|c|c|c|}
\hline & $\begin{array}{c}\text { Reindeer } \\
\text { (Rangifer } \\
\text { tarandus })\end{array}$ & Livestock & $\begin{array}{c}\text { Fur- } \\
\text { bearing } \\
\text { animals }\end{array}$ & Fish & Birds & Other & Reference \\
\hline Oravaisensaari & 54 & 167 & 8 & 24 & 17 & 1 & Salmi 2011 \\
\hline Ylikylä & 26 & 55 & 1 & 4 & 3 & - & Salmi 2011 \\
\hline Björsbyn & 22 & 526 & 1 & 6 & 5 & 166 & $\begin{array}{c}\text { Liedgren \& } \\
\text { Bergman 2015 }\end{array}$ \\
\hline
\end{tabular}

Market places and towns (ca 1300-1700)

\begin{tabular}{|l|c|r|r|r|r|r|l|}
\hline & $\begin{array}{c}\text { Reindeer } \\
(\text { Rangifer } \\
\text { tarandus })\end{array}$ & Livestock & $\begin{array}{c}\text { Fur- } \\
\text { bearing } \\
\text { animals }\end{array}$ & Fish & Birds & Other & Reference \\
\hline Kyrkudden* & 8 & 32 & 3 & 8 & 2 & - & $\begin{array}{c}\text { Vretemark } \\
1995\end{array}$ \\
\hline Gamla Kyrkbyn & 76 & 4162 & 123 & 58 & 31 & 798 & Backe 1995 \\
\hline Markkina & 1604 & 57 & 25 & 695 & 309 & 2 & $\begin{array}{l}\text { Harlin et al. } \\
2019\end{array}$ \\
\hline Tornio & 85 & 2975 & 258 & - & 630 & 91 & Puputti 2010 \\
\hline
\end{tabular}

* Faunal remains quantified only as MNI.

Upper Lapland dwelling sites (ca 1000-1650)

\begin{tabular}{|l|c|c|c|c|c|c|c|}
\hline & $\begin{array}{c}\text { Reindeer } \\
\text { (Rangifer } \\
\text { tarandus })\end{array}$ & Livestock & $\begin{array}{c}\text { Fur- } \\
\text { bearing } \\
\text { animals }\end{array}$ & Fish & Birds & Other & Reference \\
\hline $\begin{array}{l}\text { Gæccevaj'njar'ga } \\
\text { 244B }\end{array}$ & 2252 & 6 & 1 & 577 & 221 & 185 & $\begin{array}{c}\text { Hambleton \& } \\
\text { Rowly-Conwy } \\
1997\end{array}$ \\
\hline Brodtkorbneset & 2293 & 18 & 8 & 322 & 3 & - & $\begin{array}{c}\text { Vretemark } \\
2019\end{array}$ \\
\hline Steintjørna & 1147 & 2 & - & 135 & 8 & - & $\begin{array}{c}\text { Vretemark } \\
2019\end{array}$ \\
\hline Nukkumajoki & 5355 & - & 7 & 11 & 4 & - & $\begin{array}{c}\text { Harlin et al. } \\
2019\end{array}$ \\
\hline Juikenttä & 1460 & - & 3 & 1142 & 311 & 2 & $\begin{array}{c}\text { Harlin et al. } \\
2019\end{array}$ \\
\hline
\end{tabular}

is possible that people living at these sites kept reindeer; as historical sources suggest that people in medieval Tornio River valley and Rovaniemi owned reindeer for transportation purposes. On the other hand, DNA analysis of ancient reindeer bone samples from Ylikylä and Oravaisensaari, dating from the 15th to the 18th century, suggests that the animals have probably been wild. Moreover, stable isotope analyses do not suggest human-influenced dietary changes in these animals (Salmi \& Heino 2019). Skeletal frequencies show that all reindeer body parts are 


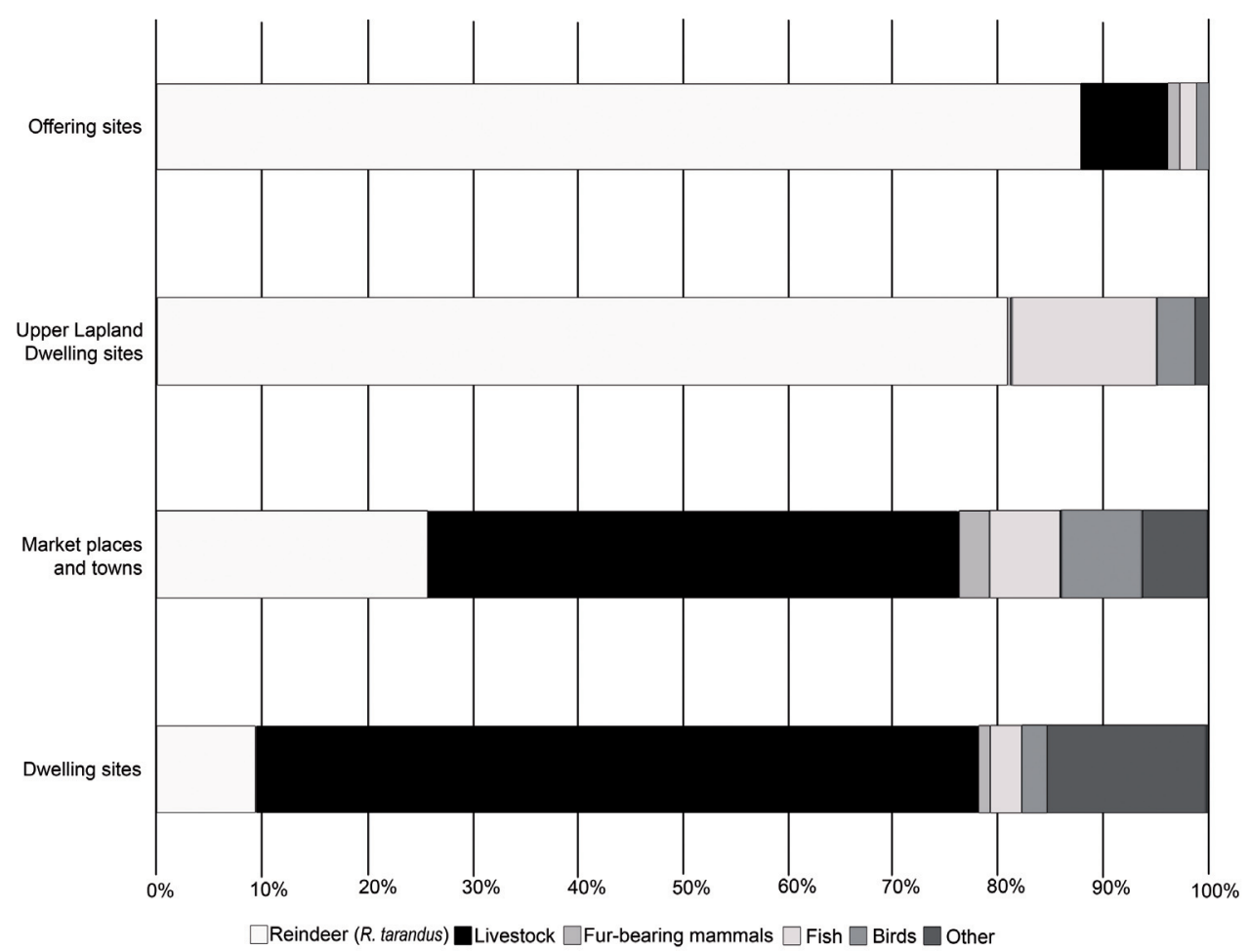

Fig. 3. Percentual distribution of faunal remains within the analysed sites.

represented in Ylikylä and Oravaisensaari, suggesting local slaughter and consumption. In Björsbyn, elements from meaty body parts are overrepresented, suggesting that some of the meat was probably imported (Salmi \& Heino 2019).

Fish bones account for ca 2-13\% of the faunal assemblages at different sites. Arctic sea fish have been discovered especially at coastal sites, but cod bones have been identified in the faunal assemblages of some inland trading places (Markkina and Pappila). The fish that was of paramount importance during the Middle Ages and the early modern period was pike (Esox lucius) - fished in quantity during the spring, as it rose to shallow inland waters to spawn, and then dried into stockfish. This variety of stockfish (Fi. kapahauki) was a highly regarded trade commodity during the Middle Ages and the early modern period, and pike was widely fished not only by inland communities, but also by coastal fishers who travelled upstream along the rivers each spring to reach inland pike fisheries (e.g. Julku 1985; Okkonen \& Heikkilä 2011, 42; Bergman 2018, 34 f.).

The zooarchaeological assemblages also hint at the importance of pike to trade. In the 13th-14th century fishing site of Älvsby 396: 1 in Sweden, the voluminous fish bone material of over 10000 fragments presented a skeletal frequency where the identified pike bones all belonged to the head region of the fish whilst vertebra 
were completely missing, indicating that only the heads were left on the site (Bergman 2018,34). This indicates drying, as the method used would have included chopping off the head, splitting the body, and hanging the fish to dry. For comparison, at the Älvsby site, another species identified in bulk was vendace (Coregonus albula) which - unlike pike - exhibited a skeletal frequency with all parts of the fish present, pointing towards local consumption (Bergman 2018, 34). A similar frequency of pike bones is displayed in another Swedish fishing site, dated to the 14th-15th centuries, by Lake Åträsk in Piteå (Bergman 2018, 35). On the Finnish side in turn this tendency is exhibited in the 13th-15th century part of the extensive Saamen museo site by Lake Inari (Ukkonen 1991), as well as in the 11th to 17th century site of Juikenttä, and the medieval Nukkumajoki complex (Harlin et al. 2019). In contrast, while the skeletal frequencies of cod and pike from the dwelling sites indicate that stockfish was processed for sale there, the zoological assemblages of trading places in turn suggest that stockfish was both sold and consumed at trading places, as in these assemblages the postcranial bones are also present (Hedman et al. 2015; Harlin et al. 2019).

Fowling has been widely practiced in northern Fennoscandia, as testified by the percentage of ca $1-8 \%$ of bird bones in the assemblages of different site types. The range of hunted species was wide, including both forest and aquatic birds. The composition of the avian assemblages reflects the season of occupation of the dwelling sites: migratory bird species were present in large numbers in the assemblage of the summer occupation site Juikenttä (Harlin et al. 2019), whereas non-migratory forest birds (Tetraonid species) dominate in the assemblages of winter sites (Hedman et al. 2015; Harlin et al. 2019). Both migratory and nonmigratory species have been present at trading and all-year dwelling sites.

Livestock bones have been identified in small amounts in some of the faunal assemblages of upper Lapland dwelling and offering sites (Hambleton \& RowleyConwy 1997; Hedman et al. 2015; Salmi et al. 2018; Vretemark 2019). Bones of sheep or goat and, to a smaller extent, cattle, are especially present. Sheep (and cattle) have been a part of the economy of some of the coastal communities (Hambleton \& Rowley-Conwy 1997; Hedman et al. 2015) perhaps from as early as ca 1000-1100 onwards (Hedman et al. 2015). Cattle was also important for the late medieval and early modern communities in the river valleys and Bothnian Bay coast, where abundant and fertile natural flood meadows were used for pasture (Lahtinen \& Salmi 2018).

The bones of fur-bearing animals account only for ca $1-3 \%$ of the faunal assemblages. The species in this category include squirrel, arctic hare, red fox, arctic fox, brown bear and wolverine, for example. The amount of bones of fur-bearing species is surprisingly small, given the traditionally strong emphasis of furs in the northern trade. Furthermore, it is historically known that especially squirrel pelts became a very important trade item in the north particularly during the 17th century (see Itkonen 1948, 41 f.; Enbuske 2008, 466), so it might be expected that furbearing animals would have a stronger representation in the archaeological material. Part of the explanation for this low occurrence may be that the carcasses of fur- 
bearing mammals were processed at the hunting sites and only the pelts were brought to the dwelling and trading sites. However, in many cases the skeletal frequencies of the fur-bearing mammals do not support this hypothesis. At the dwelling and trading sites from where we have information of the skeletal frequencies of fur-bearing animals, both long bones and crania - not only extremities that could be expected to be attached to the pelt - are present (Puputti 2010; Harlin et al. 2019), indicating that at least some of these animals were brought to and processed at the investigated sites. Season of occupation may explain the small number of bones of fur-bearing species at warm season sites, such as Juikenttä (Harlin et al. 2019), but many dwelling sites have been interpreted as winter settlements (Hedman et al. 2015; Halinen 2019). Because fur-bearing animals would have mostly been hunted during the winter when the quality of their fur is at its highest, one would expect that the majority of the bones would be found in winter settlements of communities focusing on fur trade.

\section{Summary of zooarchaeological evidence}

In summary, reindeer were probably consumed, traded and used for transportation by the majority of the communities in northern Fennoscandia throughout the Late Iron Age and Middle Ages up to the early modern period. Reindeer were central in the subsistence economy and religion of the inland communities since ca 1000 onwards, as testified by the faunal assemblages of dwelling sites and, from the 13th century onwards, of offering sites. The importance of reindeer product trade can be seen in the faunal assemblages of trading places. The faunal assemblages of the northernmost trading places are relatively clearly dominated by reindeer. Furthermore, the faunal remains represent only a fraction of the reindeer products traded at these places, as the bones were discarded in the production of hides and leather goods. Reindeer were also a part of the subsistence economy of the inhabitants of the coastal areas, the Rovaniemi region, and the Tornio River valley, and therefore meat was also an important trade commodity. Moreover, draft reindeer were a crucial part of the trade infrastructure in this area (Kortesalmi 2008, 29-109; Salmi \& Heino 2019).

Other animal products, such as fish, fowl, furs and livestock were also traded in this area. Stockfish trade is evident in the skeletal frequencies of pike and cod from the northernmost dwelling and trading sites. Pike is historically known to have been an hugely important trade article, so it is probable that the pike bones preserved in the faunal assemblages are somewhat underrepresented, but even with this caveat, the role of pike as the most important trade fish does come across relatively clearly. Considerable amounts of livestock, especially cattle bones from the trading places and dwelling sites in the Tornio River Valley, Rovaniemi, and the Bothnian Bay coast, testify to the importance of animal husbandry and dairy economy among the communities in these areas, especially during the later Middle Ages. The shares of bones of fur-bearing mammals in contrast are modest. Even when considering that the carcasses of fur-bearing mammals may have in many cases been processed at 
the hunting site and that the bones were not attached to the processed pelts taken to the trading places, the volume of fur trading seems to be minor in comparison with the economic importance of reindeer and pike.

\section{The wider context and the birth of the northern network}

The evidence reviewed suggests that the northern trade network began working in earnest during the Viking Age. This is not to claim that the network would have come into existence at that time per se - interaction and trade with the north and the rest of Europe can certainly be traced via archaeological evidence much further into the past - but it seems evident that an intensification of trade in hitherto unseen levels did begin around the Viking Age. Therefore, we put forward the suggestion that the initial motor for this intensification was a combination of several factors: the economic renewal of Europe (largely due to the economic reforms in the Central European regions following the administrative reorganisations begun by Charlemagne), the European demand for fish, and the ample supply of pike in the northern inland waters. We shall clarify this argument further.

By the beginning of the ninth century, the conquests and following reforms instigated by Charlemagne had stabilised the Central European regions both politically and economically, and trade was being consciously stimulated by the crown together with a reform of the coinage system. As a result, trade, and longdistance trade specifically, developed (Hodges 1989, 153 f.; 2012, 6 f.; Blockmans \& Hoppenbrouwers 2007, 79 ff.). Although the Carolingian empire experienced challenges quickly after the death of Charlemagne, the economic reforms had fulfilled their role and were perhaps even aided further by the Scandinavian movements that began in the ninth century (see Innes 2007, $452 \mathrm{f}$.). This relatively stable Central Europe, with its developed trade system, was one prerequisite for the rise of the northern trade; other prerequisites include Catholicism and increasing urbanisation. In the wake of Charlemagne's conquests and reforms, the church also - with the support of the crown - went through a period of reform and stabilisation. This "correction" of the Christian faith centred on doctrine, and correct observation of what was conceived to be the traditional Christian practices and liturgy, as well as the unification of the previously mosaic-like Christian world, and the professionalisation of the position of the priest (see Innes 2007, 456-480). From the perspective of northern trade, such a reform would have had one significant outcome in the likely increase in the demand for fish in Christian Europe. During Lent, the consumption of meat would have been prohibited, whilst fish would have been allowed, resulting in an increased demand for fish products. James Barrett, together with others in turn, posit that although the Christian faith was probably a factor in the increasing demand for fish, the general increase in urban populations and the corresponding demand for relatively cheap protein source with a long shelflife probably had a larger impact (Barrett et al. 2011, $1522 \mathrm{f}$.). Both factors most likely played a role in the growing demand for fish and resulted in the historically known lucrative northern fish trade (Wallerström 1983, 34 ff.; Vahtola 1990; 1997, 
73 f.; Sawyer \& Sawyer 1993, 158 f.; Hoffman 1997, 68 ff.), drawing the attention of Central European traders. It is known that the Hanseatic League ships directly sailed into the Bothnian Bay already during the early 13th century (Vahtola 1990) and it is thus plausible to assume that Central European merchants made trading trips into the north already during the preceding centuries.

During the Viking Age, the fish that would have been a viable export was pike. Whilst salmon would rise to prominence later in the historical period, the high fat content of salmon meat did not make it a trade commodity prior to the introduction of suitable quantities of salt. Pike of the inland waters in contrast was lean and easy to preserve by drying. As the meat lost water during the drying process, it was also relatively lightweight and could be moved in large quantities.

As the zooarchaeological evidence examined before has demonstrated, there appears to be relatively clear indications of the trade-economic significance of pike during the Middle Ages in the north, and we suggest that it was specifically the fish trade that functioned as the initial motor causing the intensification of the northern trade from the ninth century onwards. Whilst it is likely that pike held a central role in the trade economy of the north, there are several indicators that point towards reindeer also having an important position, but when exactly did reindeer become important? The offering site assemblages shed some light on this question.

The northern offering sites were used for multiple purposes, but interestingly there appears to be no systematic difference in offerings between different regions - e.g., mountain or forest regions - but rather, the offerings reflect a combination of economic and spiritual concerns of the groups of people using the sites. Moreover, the offering sites seem to reflect a common and shared way of reciprocating the land for taken resources in turn indicating - if not the same then similar - base for the economic strategies for the groups (Salmi et al. 2018).

A degree of chronology is visible in the offerings with the oldest species being pike, swan and bear, while metal goods were prominently offered during the late Viking Age around 1000 (Zachrisson 1984; Äikäs 2015; Salmi et al. 2018). During this time at the latest, we can with some certainty connect trade and wealth with offering sites: metal artefacts, either traded or made of traded materials, directly represent wealth gained via the trade network and firmly establish a link between the offering sites and the trade economic practices of the northern communities. It also indicates that, after this time, the offerings left at the sites can plausibly be examined from a trade economic perspective.

Around 1200, reindeer bones begin to increasingly appear in the offering site assemblages, reaching a peak during the 15th and 17th centuries (Salmi et al. 2018, 479). Reindeer pelts were exported to England during the early 14th century at the latest (Pilø et al. 2018, 1), so it is possible that this trade could have begun slightly earlier. Pilø and others (2018) have, however, concluded that reindeer hunting appears to have peaked in southern Norway's mountainous region between the 9th and 11th centuries before subsequently declining, although hunting seems to have remained prominent until the 16th century (Pilø et al. 2018, 4 ff.). Pilø et al. do not necessarily attribute the post-11th century decline in hunting-related materials to a 
decline in hunting activity per se, but rather suggest that new mass hunt techniques might have been adopted after the 11th century, resulting in the decline of archaeological material relating to the use of stalking-based hunting utilising bows and arrows (Pilø et al. 2018, 7). The research of Svein Indrelid and Anne Hufthammer (2011) lends support to this interpretation as they have dated the remains of mass hunts of reindeer - resulting in several tons of meat and other reindeer products - in the southern Norwegian mountain region to the 13th century, i.e., precisely to the time when reindeer bones also appear in the northern offering sites.

It could be said that the southern Norwegian cases have nothing to do with northern Fennoscandia, as these regions represent different cultural and topographical spheres, but this would be a hasty conclusion, as both regions were interlinked via their association with the larger northern European trade network. Therefore, processes affecting the network in total would affect both regions. In this case, the signs of mass reindeer hunts in the southern Norwegian mountainous regions and the coeval appearance of reindeer remains in the northern offering sites are indicative of such a process pertaining to the general increase in the importance of reindeer. Archaeological evidence does therefore indicate that reindeer became an important part of the northern trade economy as the Middle Ages progressed, possibly around the turn of the 13th century.

\section{Post-14th century}

After, or during the 14th century, a change - perceivable both in archaeological and archaeozoological records - occurs. The archaeological finds in the north decrease considerably (Fig. 2) which might indicate problems in trade. However, several trade hubs with rich find material signifying continuing European trade, dating to the 14th century or later, are known in the north (e.g., Wallerström 1995; Hakamäki \& Ikäheimo 2015; Kuusela et al. 2016), so it is unlikely the change would reflect a significant decrease in trade, but rather a cultural transformation which may, for example, include factors such as the slow process of northern Christianisation (Puolakka 2019; Kuusela in press), and the growing influence of the Kingdom of Sweden in the north after the 14th century (Kuusela et al. 2018). At the moment, this matter is far from clear and future research on the subject will hopefully bring further insights into this archaeologically perceptible transformation. From the perspective of the present paper, however, interesting changes appear also pertaining to the reindeer during this time.

Ancient DNA studies conducted from ancient reindeer remains from northern Norway and Finland suggest that a major genetic change occurred in the northern reindeer stocks during the Late Middle Ages - i.e., the 15th and 16th centuries (Bjørnstad et al. 2012) - and Bjørnstad et al. link this change with reindeer herding economy eclipsing the hunting economy. However, other studies complicate this view, and Salmi and Heino, for example, conclude that the reindeer remains from the 15th to 18th centuries in Ylikylä (Rovaniemi) and Oravaisensaari (Tornio) are 
likely to be from wild individuals (Salmi \& Heino 2019, 272 f.) thus indicating the importance of the hunting economy well into - and after - the Middle Ages. Moreover, extensive hunting pit systems, for instance, in the Varanger area in northern Norway, actively used until the early 17 th century, point towards the importance of wild reindeer hunting long after the Middle Ages (Hansen \& Olsen 2014, $174 \mathrm{ff}$.). It therefore seems unlikely that the period between the 15th and 16th centuries would have seen an eclipse of the hunting economy per se, but that changes did begin after the 14th century is evident.

The authors must concede the point that at this time evidence does not allow us to make decisive conclusions as to what exactly caused the change, but enough evidence may exist to present an interpretation - albeit a tentative one. Firstly, it is most likely that significant steps towards a herding economy were taken after the 14th century, even if these steps did not result in a full-fledged pastoralism until maybe well into the 18th or 19th centuries, as suggested by Bjørklund (2013). Secondly, it is plausible that these developments were connected with larger events that influenced the trade network. The evident dating of the change after the 14th century coincides with the Black Death plague epidemic. The north apparently was not spared as it is assumed that $60 \%$ of the population of Norway died in a short period (Benedictow 2004, 383). For example, Ingrid Sommerseth (2011) has raised the Black Death as a possible cause for the changes in the inland communities' economic strategies that ushered in reindeer pastoralism, though she makes the observation that as the northern inland communities did not live in close proximity, it is uncertain how susceptible they might have been to the disease (Sommerseth 2011, 122).

Another suggested factor pushing people toward reindeer pastoralism is the depletion of wild reindeer populations due to overhunting resulting from the demands of the market and taxation imposed by the emerging northern states (e.g., Vorren 1977; Odner 2001). Considering that it does seem probable that mass hunting techniques were adopted during the 13th century, this suggestion is not without merit. Nevertheless, large-scale extinctions of wild reindeer populations during this period remain speculative, especially as wild reindeer hunting continued to be a significant source of livelihood in many areas (e.g., Hansen \& Olsen 2014, 174 ff.), and there are historical indications of a strong wild reindeer population in northern Finland as late as the mid-18th century (Tegengren 1952).

It is unlikely that any one event could have ushered in significant changes among the northern communities without support from favourable underlying societal structures. Only when the societal structures of the inland communities had already developed so that reindeer herding was seen as a viable option, could phenomena, such as the Black Death or diminishing wild reindeer stocks or a combination thereof, have acted as the catalysts required to speed up the process. It is thus these structural conditions that are of interest. Hansen \& Olsen (2014, $195 \mathrm{ff}$.) argue that the management of the wild reindeer hunting infrastructure, especially the fence systems, eventually led to the emergence of organisational leadership and individual ownership of animals (2014, 203 ff.). In addition, Sommerseth (2011) makes note 
that, if there was a crisis after the mid-14th century, the hunters would have likely faced a problem of a disproportion between the demand and supply of hunting goods, and if the inland communities were hit by the Black Death, they may have faced a problem of insufficient personnel to organise successful hunting parties (Sommerseth 2011, 123; Pilø et al. 2018, 7). It has also been suggested that the demands of the market for reindeer products was so extensive that the hunters needed to find ways to increase their productivity (Hedman 2003, $223 \mathrm{ff}$.).

These factors might have turned the attention of hunters towards focusing more on reindeer herding, but both Sommerseth and Thomas Wallerström have pointed out that this move might have not been intended to supplant the hunting economy, but rather to support it (Wallerström 2000, 10 ff.; Sommerseth 2011, 123). Furthermore, it is possible - even probable - that herding was still mostly a form of subsistence and a source of raw materials necessary for everyday life, and not commercial herding (Sommerseth 2011, 123). The zooarchaeological record examined previously supports the idea that commercial hunting remained the primary trade economy in the north well through the Middle Ages and into the early modern period. From this perspective, those centuries following the 14th century do not present themselves as a radical change in the social structures of the inland communities. It would appear rather that reindeer herding began to be more emphasised in the economic structures of the inland communities while the hunting economy still retained its strong position.

Motivations for the inland communities to increase the emphasis of domesticated reindeer in their economic strategies following the 14th century can be viewed as a strategy to alleviate pressure that was directed on their primary commercial hunting economy. The inland communities probably faced problems during the late 14th century and the 15th century which impacted on their ability to meet the demands of the trade network. A common way to respond to the increasing demand is to increase production, but if this is not an option - as it may have been for the inland communities - another option could have been to take pressure off the hunting economy by lessening its role in the subsistence economy; increased emphasis on domesticated animals would have served this purpose. As Ivar Bjørklund (2013) has convincingly argued, however, domestication during this time could by no means have taken the role of a primary subsistence economy, but as a supporting element, it could have worked to mitigate excessive economic pressure by freeing resources - previously targeted towards subsistence hunting - towards commercial hunting.

\section{Conclusions}

The trade incomes of northern communities during the Late Iron Age and Middle Ages were tied exclusively to hunting and fishing, but this appears to be the case only from the start of the Late Iron Age. Prior to the Late Iron Age, the coastal regions have a more pronounced archaeological profile than inland regions, as testified by the clustering of sites and finds (Kuusela 2014). During the course of 
the Iron Age, a gradual change in this trend is observable with the Viking Age being a watershed period. This indicates that activity resulting in an archaeological record increased in the inland region, and coupled with the economic analysis of the north, we suggest this change is tied to the rise of commercial fishing and hunting, and related trade brought about by economic developments in Central Europe following the eighth century. During the Viking Age, the offering sites start seeing copious deposits of imported trade goods, while at the same time the faunal assemblages of dwelling sites are being dominated by reindeer, with pike standing out among the fish remains.

While the increase in economic activity on a larger scale is tied to the panEuropean economic surge during the Viking Age, reaching the north via the interaction network that had been in existence for millennia (Kuusela 2013; Hakonen et al. 2017), a change that resulted in a specific interest on the inland regions appeared. This change was a growing interest towards, and a demand of, inland products. There is little reason to doubt that furs would have been a valuable commodity, but the question is ultimately one of volume. Whereas furs may have been individually valuable, the faunal assemblages suggest their volume in traded units may have been surpassed by a fair margin by other animal products, with reindeer taking the first place as the most important land animal in terms of volume, and pike dominating the fish trade.

Faunal assemblages indicate that reindeer reached a new level of importance for the inland people around the 13th century when reindeer bones begin appearing in offering sites, and concurrent signs of mass reindeer hunts appear. Roughly around the same time, the number of archaeological sites and finds peaks in the north (Fig. 2). In addition, silver and metal deposits - or hoards - peak during the 11th and 13th centuries both in Sweden and especially in Finland, and, in general, the northern assemblages indicate a wide contact network reaching across all of Europe and points beyond (Kuusela et al. 2016; 2018; Hakamäki 2018).

This then brings us to the observation that the birth of the northern Fennoscandian trade network that was in existence during the Early Middle Ages should be dated to the Viking Age, albeit it was built on a pre-existing network of interaction that had been in existence for millennia prior to the Viking Age. Based on faunal assemblages, this trade was integrally linked with hunting and fishing, specifically, the hunting of reindeer and the fishing of pike.

\section{Acknowledgements}

This work was supported by the Finnish Cultural Foundation under Grant 00190586 (Jari-Matti Kuusela); Academy of Finland under Grant 285774 (AnnaKaisa Salmi); and European Research Council under Grant StG 756431 (Anna-Kaisa Salmi). The publication costs of this article were covered by the Estonian Academy of Sciences, the Institute of History and Archaeology at the University of Tartu, and the Institute of History, Archaeology and Art History of Tallinn University. 


\section{References}

Äikäs, T. 2015. From Boulders to Fells. Sacred Places in the Sámi Ritual Landscape. Translated by S. Silvonen. The Archaeological Society of Finland, Helsinki.

Backe, M. 1995. Osteologisk analys av benmaterial från G:a Kyrkbyn. - Norrbotten, Sverige och medeltiden. Problem kring makt och bosättning i en europeisk periferi. Del 2: bilagor. Ed. T. Wallerström. Almqvist and Wiksell International, Stockholm, 81-96.

Barrett, J. H. 2016. Studying medieval sea fishing and fish trade: how and why. - Cod and Herring. The Archaeology and History of Medieval Sea Fishing. Eds J. H. Barrett \& D. C. Orton. Oxbow Books, Oxford, 1-10.

Barrett, J. H. 2019. An environmental (pre)history of European fishing: Past and future archaeological contributions to sustainable fisheries. - Journal of Fish Biology, 94: 6, 1033-1044.

Barrett, J. H., Orton, D., Johstone, C., Harland, J., Neer, W. Van, Ervynck, A., Roberts, C., Locker, A., Amundsen, C., Bødker Enghoff, I., Hamilton-Dyer, S., Heinrich, D., Hufthammer, A. K., Jones, K. G. J., Jonsson, L., Makowiecki, D., Pope, P., O'Connell, T. C., Roo, de R. \& Richards, M. 2011. Interpreting the expansion of sea fishing in medieval Europe using stable isotope analysis of archaeological cod bones. - Journal of Archaeological Science, 38, 1516-1524.

Benedictow, O. J. 2004. The Black Death, 1346-1353. The Byodell Press, Woodbridge.

Bergman, I. 2018. Kulturarv, landskap och identitetsprocesser i norra Fennoskandien 500-1500 e.Kr. Slutrapport från ett forskningsprogram. Riksbankens jubileumsfond, Stockholm.

Bergman, I. \& Edlund, L.-E. 2016. Birkarlar and Sámi. Inter-cultural contacts beyond state control: Reconsidering the standing of external tradesmen (birkarlar) in medieval Sámi societies. - Acta Borealia, 33: 1, 52-80.

Bjørklund, I. 2013. Domestication, reindeer husbandry and the development of Sámi pastoralism. Acta Borealia, 30: 2m, 174-189.

Bjørnstad, G., Flagstad, Ø., Hufthammer, A. K. \& Røed, K. H. 2012. Ancient DNA reveals a major genetic change during the transition from hunting economy to reindeer husbandry in northern Scandinavia. - Journal of Archaeological Science, 39, 102-108.

Blockmans, W. \& Hoppenbrouwers, P. 2007. Introduction to Medieval Europe 300-1550. Routledge, London.

Enbuske, M. 2008. Vanhan Lapin valtamailla. Asutus ja maankäyttö Kemin Lapin ja Enontekiön alueella 1500-luvulta 1900-luvun alkuun. Suomalaisen Kirjallisuuden Seura, Helsinki.

Hakamäki, V. 2018. Seeing Behind Stray Finds. Understanding the Late Iron Age Settlement of Northern Ostrobothnia and Kainuu, Finland. University of Oulu, Oulu.

Hakamäki, V. \& Ikäheimo, J. 2015. Iin Illinsaaren Pirttitörmä: asuinpaikka rautakauden ja keskiajan taitteesta. - Faravid, 39, 7-22.

Hakamäki, V. \& Kuusela, J.-M. 2013. Examining the topography and social context of Metal Age artefact finds in northern Finland. - Fennoscandia Archaeologica, 30, 95-106.

Hakonen, A., Hakamäki, V. \& Kuusela, J.-M. 2017. Observing social change on the Bothnian Bay coast in the 1st millennium BC: The burials of Tahkokangas and the community of the Oulujoki River estuary. - Assemblage, 15, 15-27.

Halinen, P. 2019. Inari Nukkumajoki 5, the excavated history of a Sámi winter village. - In Search of Hearths. A Book in Memory of Sven-Donald Hedman. Eds P. Halinen \& B. Olsen. Finnish Antiquarian Society, Helsinki, 96-122.

Hambleton, E. \& Rowley-Conwy, P. 1997. The medieval reindeer economy at Gæccevaj'njar'ga 244 B in the Varanger Fjord, north Norway. - Norwegian Archaeological Review, 30: 1, 55-70.

Hansen, L.-I. \& Olsen, B. 2014. Hunters in Transition: An Outline of Early Sámi History. Brill, Leiden. Harlin, E.-K., Mannermaa, K. \& Ukkonen, P. 2019. Animal bones from medieval and early modern Saami settlements in Finnish Lapland. - Helsinki Harvest. Proceedings of the 11th Nordic Conference on the Application of Scientific Methods in Archaeology. Eds K. Mannermaa, M. A. Manninen, P. Pesonen \& L. Seppänen. The Archaeological Society of Finland, Helsinki, 149-177. 
Hedman, S.-D. 2003. Boplatser och offerplatser: ekonomisk strategi och boplatsmönster bland skogssamer 700-1600 AD. Umeå universitet, Umeå.

Hedman, S.-D., Olsen, B. \& Vretemark, M. 2015. Hunters, herders and hearths. Interpreting new results from hearth row sites in Pasvik, arctic Norway. - Rangifer, 35: 1, 1-24.

Henriksen, J. E. 2019. Trade, manufacture, dismantling and reassembling? Metal processing and eastern ornaments at Brodtkobneset and Steintjørna. - In Search of Hearths. A Book in Memory of Sven-Donald Hedman. Eds P. Halinen \& B. Olsen. Finnish Antiquarian Society, Helsinki, 40-66.

Hodges, R. 1989. Dark Age Economics. The Origins of Towns and Trade AD 600-1000. Second edition. Duckworth, London.

Hodges, R. 2012. Dark Age Economics. A New Audit. Bristol Classical Press, London.

Hoffman, E. 1997. Hansakaupungit ja pohjoismaat. - Margareeta - pohjolan rouva ja valtias. Kalmarin unioni 600 vuotta. Ed. H. Edgren. Nationalmuseet, Copenhagen, 67-74.

Indrelid, S. \& Hufthammer, A. K. 2011. Medieval mass trapping of reindeer at the Hardangervidda mountain plateau, south Norway. - Quaternary International, 238, 44-54.

Innes, M. 2007. Introduction to Early Medieval Western Europe, 300-900. The Sword, the Plough and the Book. Routledge, London.

Itkonen, T. I. 1948. Suomen lappalaiset vuoteen 1945, I. WSOY, Helsinki.

Julku, K. 1985. 1500-luku. - Faravidin maa. Pohjois-Suomen historia. Ed. K. Julku. Kustannusosakeyhtiö Pohjoinen, Oulu, 148-199.

Kortesalmi, J. J. 2008. Poronhoidon synty ja kehitys Suomessa. Suomalaisen Kirjallisuuden Seura, Helsinki.

Kuusela, J.-M. 2013. Political Economy of Bronze- and Iron Age Societies in the Eastern Coast of the Bothnian Bay ca 1500 BC-AD 1300. University of Oulu, Oulu.

Kuusela, J.-M. 2014. From coast to inland. Activity zones in northern Finland during the Iron Age. Fibula, Fabula, Fact. The Viking Age in Finland. Eds J. Ahola, Frog \& C. Tolley. SKS, Helsinki, 219-241.

Kuusela, J.-M. 2015. Iin Illinsaaren Suutarinniemen myöhäisrautakautinen kalmisto ja sen konteksti. - Faravid, 40, 5-30.

Kuusela, J.-M. 2018. Food and tension. Feasting as means to alleviate social tension in the 14th15th century trading places of Bothnian Bay region. - World Archaeology, 50: 2, 323-336.

Kuusela, J.-M. in press. La lente christianisation des côtes septentrionales de la Finlande: une perspective archéologique. - Revue d'Historie Nordique.

Kuusela, J.-M., Nurmi, R. \& Hakamäki, V. 2016. Co-existence and colonisation. Re-assessing the settlement history of the pre-Christian Bothnian Bay coast. - Norwegian Archaeological Review, 49: 2, 177-203.

Kuusela, J.-M., Nurmi, R. \& Hakamäki, V. 2018. Unhierarchical and hierarchical core-periphery relations: North Fennoscandian trade network from the Middle Ages to the post-sixteenth century. American Anthropologist, 120: 4, 766-780.

Lahtinen, M. \& Salmi, A.-K. 2018. Farming in the extreme - Animal management in late medieval and early modern northern Finland. - Arctic Anthropology, 55: 2, 76-96.

Liedgren, L. \& Bergman, I. 2015. Gustaf Hallströms utgrävning 1921 av en senmedeltida gård i Björsbyn utanför Luleå i Norrbotten. - Fornvännen, 110, 184-200.

Martin, J. 1986. Treasures of the Land of Darkness: The Fur Trade and Its Significance for Medieval Russia. Cambridge University Press, Cambridge.

Martin, J. 1995. Medieval Russia 980-1584. Cambridge University Press, Cambridge.

Odner, K. 2001. Trade, tribute and household responses. The archaeological excavation at Geahèevájnjárga 244B in Varanger fjord, northern Norway. - Acta Borealia, 18: 1, 25-50.

Okkonen, J. \& Heikkilä, J. 2011. Pohjois-Suomen kalapatojen historiaa - havaintoja viidestä sisävesikohteesta. - Faravid, 35, 29-43.

Pilø, L., Finstad, E., Bronk Ramsey, C., Martinsen, J. R. P., Nesje, A., Solli, B., Wangen, V., Callanan, M. \& Barrett, J. H. 2018. The chronology of reindeer hunting on Norway's highest ice patches. - Royal Society Open Science, 5, 171738. 
Puolakka, H. 2019. Cremation burials in inhumation cemeteries in Late Iron Age Finland and the Karelian Isthmus. - Transactions of the Institute for the History of Material Culture, 20, 53-63.

Puputti, A.-K. 2010. Living with Animals: A Zooarchaeological Study of Human-Animal Relationships in Early Modern Tornio, 1621-1800. Archaeopress, Oxford.

Salmi, A.-K. 2011. Riistaa, kalaa ja konttiluita - Pohjois-Suomen maaseudun ruokakulttuurista n. 1400-1700. - Harmaata näkyvissä. Kirsti Paavolan juhlakirja. Eds J. Ikäheimo, R. Nurmi \& R. Satokangas. University of Oulu, Oulu, 221-236.

Salmi, A.-K. \& Heino, M. 2019. Tangled worlds: The Swedish, the Sámi, and the reindeer. International Journal of Historical Archaeology, 23: 1, 260-282.

Salmi, A.-K., Äikäs, T., Spangen, M., Fjellström, M. \& Mulk, I.-M. 2018. Tradition and transformation in Sámi animal offering practices. - Antiquity, 92: 362, 472-489.

Sawyer, B. \& Sawyer, P. 1993. Medieval Scandinavia. From Conversion to Reformation circa 8001500. University of Minneapolis Press, Minneapolis.

Sommerseth, I. 2011. Archaeology and the debate on the transition from reindeer hunting to pastoralism. - Rangifer, 31, 111-127.

Star, B., Boessenkool, S., Gondek, A. T., Nikulina, E. A., Hufthammer, A. K., Pampoulie, C., Knutsen, H., André, C., Nistelberger, H. M., Dierking, J., Petereit, C., Heinrich, D., Jakobsen, K. S., Stenseth, N. C., Jentoft, S. \& Barrett, J. H. 2017. Ancient DNA reveals the arctic origin of Viking Age cod from Haithabu, Germany. - PNAS, 114: 34, 8152-9157.

Tegengren, H. 1952. En utdöd lappkultur i Kemi lappmark: studier i Nordfinlands kolonisationshistoria. Åbo Akademi, Åbo.

Ukkonen, P. 1991. Inari 13 Saamen museo (KM 26611, KSAAME). Luuanalyysi 31.10.1991. Report of a zooarchaeological analysis of faunal bones. National Board of Antiquities, Helsinki.

Vahtola, J. 1990. Erstrecte sich der deutsche Handel im Mittelalter bis an die finnische Küste am Ende des Bottnischen Meerbusens? - Jahrbücher für Geschichte Osteuropas, 38: 2, 161-177.

Vahtola, J. 1997. Kemijoen asutuksen synty ja kehitys vuoteen 1600. - Keminmaan historia. Eds P. Koivunen, J. Vahtola, R. Satokangas \& M. Itkonen. Keminmaan kunta \& Keminmaan seurakunta, Keminmaa, 56-85.

Vorren, Ø. 1977. Mennesket og reinen. - Ottar, 101, 5-11.

Vretemark, M. 1995. Analys av benmaterial från Kyrkudden. - Norrbotten, Sverige och medeltiden. Problem kring makt och bosättning i en europeisk periferi. Del 2: bilagor. Ed. T. Wallerström. Almqvist and Wiksell International, Stockholm, 182-190.

Vretemark, M. 2019. The faunal remains from two hearth-row sites in Pasvik, arctic Norway. - In Search of Hearths. A Book in Memory of Sven-Donald Hedman. Eds P. Halinen \& B. Olsen. Finnish Antiquarian Society, Helsinki, 67-74.

Wallerström, T. 1983. Kulturkontakter i Norrbottens kustland under medeltiden. - Norrbotten, 82$83,16-55$.

Wallerström, T. 1995. Norrbotten, Sverige och medeltiden. Problem kring makt och bosättning i en europeisk periferi. Del 1. Almqvist \& Wiksell International, Stockholm.

Wallerström, T. 2000. The Saami between east and west in the Middle Ages: An archaeological contribution to the history of reindeer breeding. - Acta Borealia, 17: 1, 3-39.

Zachrisson, I. 1984. De samiska metalldepåerna år 1000-1350 i ljuset av fyndet från Mörträsket, Lappland. Umeå universitet, Umeå. 


\section{Jari-Matti Kuusela, Anna-Kaisa Salmi ja Tiina Äikäs}

\section{JAHIMEHED, KALASTAJAD, KAUPMEHED - ARHEOLOOGILINE JA ZOOARHEOLOOGILINE VAATENURK PÕHJA-FENNOSKANDIA KAUBANDUSVÕRGU ARENGULE HILISRAUAAJAL NING KESKAJAL}

\section{Resümee}

Artiklis on uuritud arheoloogilistele ja zooarheoloogilistele andmetele toetudes kaubavahetuse teket Põhja-Fennoskandias. Ajavahemikus 800-1600 toimus PõhjaFennoskandias kiire majanduslik ja ühiskondlik areng, nende sajandite jooksul sai Põhja-Fennoskandiast Balti regiooni kujunevate riikide vahelise võimuvõitluse tanner. Samuti algas ristiusustamine ja põhjapõtrade kodustamine ning kasvatamine koos nendest johtuvate kultuuriliste muudatustega. Nende arengute keskel oli alates viikingiajast Euroopal majanduslik huvi Põhja-Fennoskandia ja sellest tulenevalt kaubavahetuse vastu. Põhja-Fennoskandia arheoloogiline ja zooarheoloogiline tõendusmaterjal näitab, et kauplemise sissetulekud hilisrauaajal ja keskajal olid seotud jahipidamise ning kalastamisega, kuid see näib kinnitust leidvat ainult alates hilisrauaaja algusest, umbes 800 . aastal. Nagu selgub asustatud kohtade tihedusest ja leidudest, oli enne hilisrauaaega rannikualade arheoloogiline profiil rohkem väljakujunenud kui sisemaa-aladel. Rauaaja jooksul saab selles täheldada järkjärgulist muutust, kus pöördeliseks perioodiks oli viikingiaeg. Seega intensiivistus tegevus sisemaadel, mis meie arvates oli põhjustatud kaubandusliku kalastuse ja jahipidamise suurenemisest, samuti kaubandusest, mida turgutas majanduslik areng Kesk-Euroopas pärast 8. sajandit. Viikingiajal levisid laialt imporditud tooted, samal ajal kui asustatud kohtades olid esikohal põhjapõdrad; kalajäänustes domineerib haug.

Majandusliku tegevuse üldine hoogustumine oli seotud üleeuroopalise majanduse kiire edenemisega viikingiajal, jõudes põhjaaladele juba tuhandeid aastaid käigus olnud võrgustiku kaudu. Järk-järgult hakkas kasvama huvi sisemaade ja nende toodangu vastu. Loomsed jäänused osutavad, et põhjapõtrade osatähtsus sisemaa elanike majanduses kasvas veelgi 13. sajandi paiku, kui ohverduskohtadele hakkasid ilmuma põdraluud, ühtlasi ilmnevad ka märgid ulatuslikust põhjapõtrade küttimisest. Umbes samal ajal saavutas haripunkti arheoloogiliste kohtade ja leidude arv. Samuti saavutasid 11.-13. sajandil kõrgpunkti hõbeda- ja metalliaarded Rootsis, aga eriti Soomes. Põhjaalade kogumid tõendavad üle terve Euroopa ja kaugemalegi ulatuvaid võrgustikke.

Sellest võime järeldada, et varasel keskajal Põhja-Fennoskandias toiminud kaubandusvõrgustiku tekke võib arvata viikingiaega. Loomsete materjalide alusel on selge, et kaubavahetus oli seotud jahipidamise ja kalastamisega, eriti põhjapõtrade jahtimise ning haugipüüdmisega. 